\title{
実験住宅における太陽光発電の有効性評価と木津中央地区への展開 A EFFICIENCY EVALUATION OF SOLAR POWER GENERATION AT AN EXPERIMENTAL HOUSE AND ITS DEVELOPMENT POSSIBILITY IN KIZU-CYUO AREA
}

\author{
今川朱美*, 内藤正明** \\ Akemi IMAGAWA and Masaaki NAITO
}

\begin{abstract}
The study is a part of the project "concept formulation and development of planning methodology of environmental symbiotic area". This research designs an experimental house fitted with building material type solar panels with an objective to curtail the environmental load and reduction in the construction cost that occurs in the usual mode of installation of the additional energy generating and saving devices. Besides solar energy system in the house, the design of the air cavity in the wall and the circulation of the air within the room that has been achieved through detail considerations in the overall design of the house, considerable curtailment in the cooling energy load has been achieved.

It has been found that the experimental house installed with the $3 \mathrm{kWh}$ capacity, which is considered to be a viable scale to a dwelling unit, saves $70 \%$ of electricity compared to those houses that use dual energy source of gas and electricity, and $40 \%$ compared to those that use only electricity. It is remarkable that the resident users became more conscious on the energy consumption with this achievement in curtailment in the energy cost The results of the experimental house has then been extended to make a simulation analysis in the residential area of Kizu-chuo.
\end{abstract}

\author{
Keywords : Solar Power Generation, Electric power charge, Cooling Energy load, Eco-housing, \\ Environmental symbiotic area planning, Kizu-Cyuo Area \\ 太陽光発電、電力消費量、冷房負荷、環境共生住宅、環境共生地域づくり、木津中央地区
}

\section{1 はじめに}

本稿は、「環境共生の概念探求と計画化」に関する研究*11の一 環として、太陽光発電を利用する住宅地区を実現することによっ て、エネルギー負荷の削減効果を明らかにしようとするものであ る。これは、同時に二酸化炭素など温室効果ガス削減にも有効で ある。いまや、個人住宅レベルでも地球環境負荷の削減対策を講 じることが期待されているので、今後の発展が望まれる。

自然エネルギーを利用するエネルギ一自立型住宅に関しては、 北海道 (札幌)において、濱田、中村、落藤ら*2)が、戸建て住宅 で太陽光発電を行った場合の電気エネルギー消費に関しては、新 潟 (仙台) で、佐々木、赤林、坂口ら*3) が、調査を行っている。 それらはいずれも寒冷地における暖房エネルギーに焦点を当てて いるが、自然エネルギーの研究では、言うまでもなく地域ごとの 自然条件が多大に影響するため、条件が異なる本島中央に位置す る対象地域での本研究は、既往研究と異なるデー夕を提供しう

る。また、戸建住宅におけるエネルギ一供給データをベースとし て、それを街区へと展開している点も、本研究の一つの意義と考 える。

本研究では、まれな例として、施主の依頼により実際に居住す る住宅を、省エネ・新エネの工夫を加えた住宅として、京都市北
区に新たに建設した（図 1)。これを今後、本報では実験住宅と 呼ぶ。

本研究では、その実験住宅に対して太陽光発電システムを導入 した時の環境負荷低減効果を実験的に精密測定、評価すると共 に、経済評価を行った。次いで、将来のエネルギー負荷削減にど のくらいの効果があるか、地域規模での大まかな推定を行う為 に、実験住宅での基礎データを基にして、京都府木津町で開発が 予定されている木津中央地区で、このシステムを採用した場合の 効果を試算した。

\section{2 太陽光発電システムの概要}

\section{2-1 太陽電池セルとモジュールの選択}

太陽光発電システムを導入するには、(1)モジュール自体に大き な費用が必要であることに加え、(2)太陽光発電を行なっても住宅 の構造が節電に適していなければ、エネルギー負荷削減に効果が 得られないこと、(3)設置コストが大きいこと、(4)景観規制などに より、地域によってはその設置が制限されること、(5)かなの荷 重がある、などの様々な障害がある。今日、国内各地で環境共生 住宅と言われる実験住宅も多く建設されているものの、これらの 点が大きく改善されない限り、その普及は難しいと思われる。

\footnotetext{
$*$ 京都大学大学院工学研究科 大学院生 $\cdot$ 建修

** 京都大学大学院工学研究科 教授. 工博
}

Graduate Student, Global Environment Engineering, Graduate School of Engineering, Kyoto Univ., M. Arch. Prof., Global Environment Engineering, Graduate School of Engineering, Kyoto Univ., Dr. Eng. 


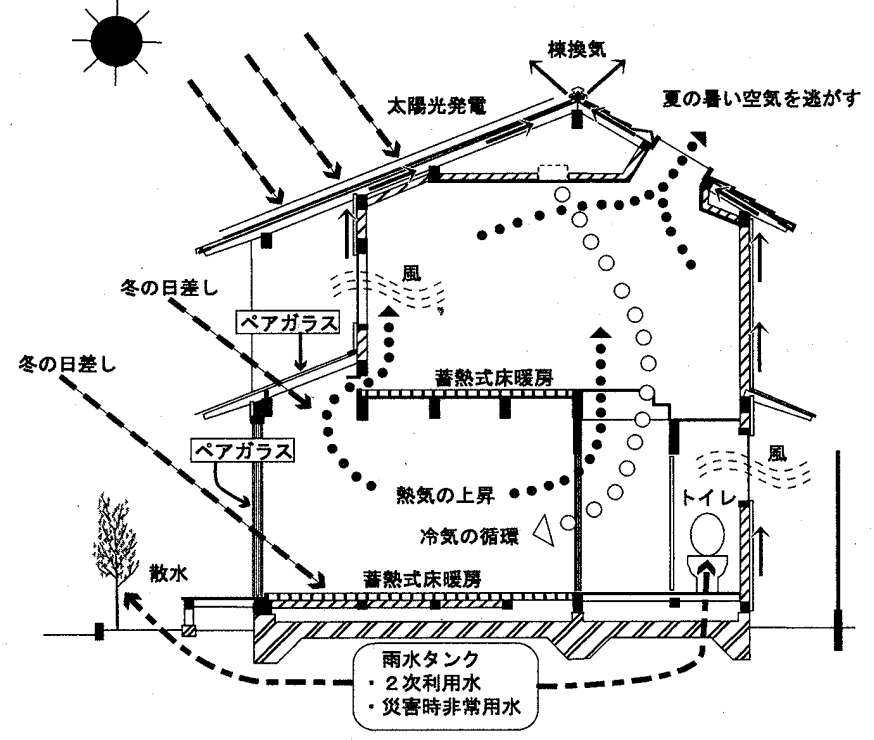

图 1 実験住宅

以上のような課題に対して、本研究では住宅用に開発されてい る太陽光発電パネルで、屋根材として利用できるものを新築時に 取り付けることにより、発電パネル設置面積分の屋根材コストの 削減を図り、また、デザイン的にも収まりがよいことで、上記問 題点(3)(4)(5)の相当程度を克服することができた。

住宅用に製品化されているシリコン (Si) 系太陽電池について は、大量生産に適した多結晶 Si を用いた素子が、安価なプロセ スでの製造方法により供給されるようになった*4)。将来の増産 による Si 原料の不足を予測し、少ない原材料で生産可能な結晶 系薄膜 Si 太陽電池が注目されているが、発電効率や生産の安定 性には、まだ技術開発の余地がある*5)。

本実験では、住宅建設時において、設備投資に踏み切れる製品 の質と価格を検討した結果、多結晶 Si の建材一体型太陽電池モ ジュールを採用することにした。モジュールの出力は直流電力で あるため、インバータで電力に変換し、電力会社の商用電力系統 と連結利用が可能な系統連系型システムとした。太陽電池が発電 中は、発電した電力を使用し、余剩分を電力会社に売電する。発 電量では電力使用量をまかなえない場合は、電力会社から供給さ れる電力と併せて使用する。

システム導入により、年間で電力需要が最大となる夏期の数日 間、しかも日中数時間の負荷平準化を期待した。また、日射量が 少なく、発電量の期待できない冬季においては、暖房に使うエネ ルギーを夜間に蓄熱することにより年間を通じ、エネルギー自立 型により近い状態の実現を目指した。

\section{表 1 実験住宅における太陽光パネルの仕様}

\begin{tabular}{|l|l|}
\hline 太陽電池セル（太陽電池素地） & 多結晶シリコン \\
\hline 太陽電池モジュール & 建材一体型太陽電池モジュール \\
\hline 太陽電池容量 & $25.0 \mathrm{~m}^{2}$ \\
\hline 設置面皘 & $2.8 \mathrm{kw}(70 \mathrm{w} \times 40$ 枚) \\
\hline 年間予測発電量 (メーカーによる全国平均) & $2,917 \mathrm{kwh} /$ 年 \\
\hline 太陽電池設置面 & 西南西 (19度) \\
\hline 太陽電池設置傾斜 & 21.3 度 (四寸勾配) \\
\hline
\end{tabular}

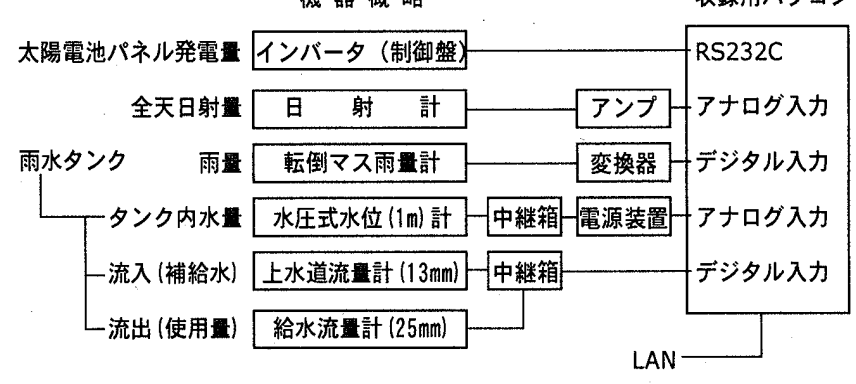

図 2 実験住宅のデータ収集システム

\section{2-2 実験住宅の概要}

実験住宅は京都市内の第一種低層住居専用地域に、延床面積約 $160 \mathrm{~m}^{2}$ の造 2 階建て住宅として建設した。合掌屋根の西南西方 向に 40 枚の建材一体型太陽電池モジュールが、21.3 度（4寸勾 配）の傾斜角で設置されている（表 1 ）。冷暖房にはルームエア コンを設置した。また、夏期の泠房負荷軽減のため、(1)日射によ り高温となる外壁を二重構造とし、壁内から天井を通過して棟の 換気口から熱気を上昇、自然排気させることで、屋内への熱の伝 導を軽減する、(2)屋内の熱気も、鉛直の動線を確保し、天空から 抜く、(3)水平の風の通り道を確保する、など様々の設計の工夫を した（図 1)。なお、冬は蓄熱式床暖房と壁の断熱効果を期待し ているが、これについては次稿にて検証したい。

実験住宅には、データ収集用パソコンが設置されており、太陽 電池による発電量などのデータが 1 分毎に記録されている（図 2)。二重構造の外壁による断熱、防湿効果については東西南北 の各一カ所の外部と内部に温湿度センサーを設置し、これも 30 分毎に記録している。

\section{3 実験住宅の電力使用量と発電量 3-1 発電量の予測}

実験住宅におけるシステムの発電量予測*6) は、斜面日射量*71 之、太陽電池容量に補正係数*8) を乗じて求めた。1 年間の予測 発電量は、2, $531 \mathrm{kWh}$ であり、これは一般家庭 (ガス併用) の年間 の平均電力使用量 $4,004 \mathrm{kWh}$ *91のうち、 $63.2 \%$ の電力に対応し、 また発電時に排出される二酸化炭素も、708.68kg-C/年*10)の排 出削減が期待できる（図 3 ）。なお、この推定值は実測値と比較 したところ、問題となる程の大差はなかったため、地域規模での 発電量予測などに汎用できると判断した。

\section{3-2 電力使用量の予測}

実験住宅居住者が、新築の実験住宅に移るまでに生活していた

\section{表 2 前住宅と実験住宅の建築及び設備概要の比較}

\begin{tabular}{|c|c|c|}
\hline & 住 宅 & 実 験 住 宅 \\
\hline 所 在 地 & 京都市左京区 & 京都市北区 \\
\hline 造 & コンクリート造 2 跸建 & 木造（2 棟） 2 階建 \\
\hline 延床面皘 & $80 \mathrm{~m}^{2}$ & $159 \mathrm{~m}^{2}$ \\
\hline $\begin{array}{l}\text { 調 理 器 具 } \\
\end{array}$ & ガス調理器 & IHクッキングヒーター \\
\hline 給 湯 設 備 & ガス給湯器 & 電気温水器 (460L) \\
\hline 備付電灯消費電力合計 & $580 \mathrm{~W}$ & $1,308 W$ \\
\hline 冷房設備消費電力合計 & $1,600 \mathrm{~W}$ & $3.180 \mathrm{~W}$ \\
\hline 暖房設備消費電力合計 & ガスストーブ & $4,960 \mathrm{~W}$ \\
\hline
\end{tabular}




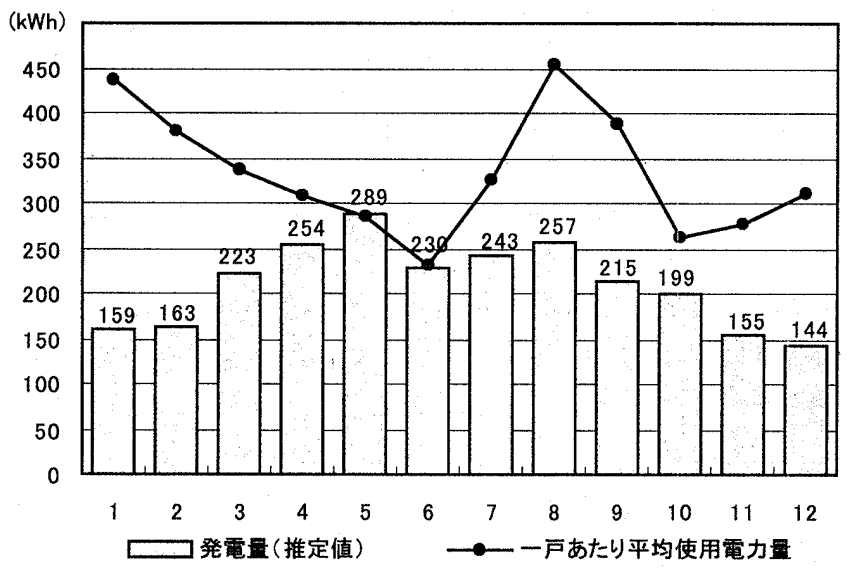

図 3 実験住宅の推定発電量と一般の電気・ガス併用家庭の平均電力使用量

住宅（以後は前住宅と呼ぶ）での実績データ（2000 年 5 月〜 2001 年 4 月）を基にして様々な比較を行った。前住宅はコンク リート造で、気密性がよく、熱効率も良い。実験住宅の延床面積 は前住宅と比べて 2 倍程度になったため（表 2)、建築条件から すると、冷暖房エネルギーの消費量が増大することが予測される が、実験住宅では、夏の通気、冬の蓄熱システムを導入してお り、それに相当する効果が期待できるため、建築物の条件による 泠暖房需要の差異の補正は省いている。

住宅に備えた電気製品の消費電力を算出すると、(1)高齢化に備 えオール電化住宅としたこと、(2)前住宅では暖房をガスに頼って いたが、蓄熱式床暖房としたこと、(3)老後のために電灯を過分に 取り付けたこと、(4)デー夕収集のためにもIT化を行い、新たに 2 台のパソコンを導入したこと、などから一ヶ月あたりの消費電 カが大幅に増加している。前住宅の電灯及び家電分の 1 ケ月あた りの電力使用量は、 $200 \mathrm{kWh} / \mathrm{M}$ 前後であったが、実験住宅では(1) から(4)の条件より、関電エリアでのガス併用一般住宅の月平均電 力使用量 $310 \mathrm{kWh} / \mathrm{M}^{* 11)}$ よりも大きくなると予測されるため、倍 増したものと設定した。

前住宅でのガス使用量より、厨房ガスと給湯ガスの使用量の合 計は、 $20 \mathrm{~m}^{3}$ を越えることはないと仮定し、厨房・給湯ガスの使 用量の比を 1：4 と定め*12)、ガスコンロを IH クッキングヒー

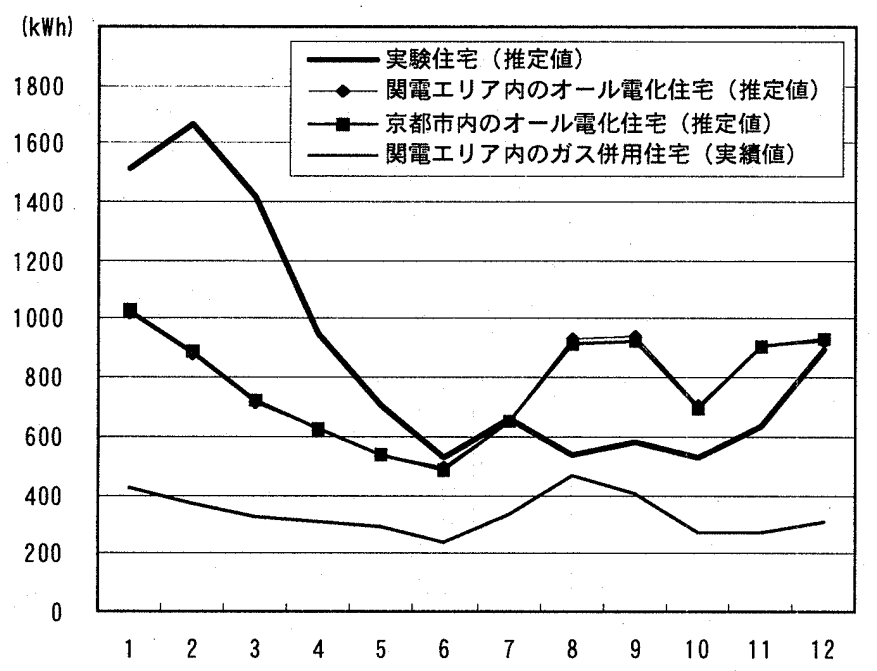

图 4 実験住宅とオール電化住宅の月別電力使用量の推定値
ターに、ガス給湯器を電気温水器に置き換えてのエネルギー消費 量を概算する。冬期の暖房ガス使用量は $20 \mathrm{~m}^{3}$ 越えた分とし、ガ スファンヒーターとエアコンで、同効力のものを使用したとして 試算した*13)。

\section{3-3 実験住宅の電力使用量と発電量}

関西電力は、関電エリアにおけるオール電化住宅の電力使用量 を $905 \mathrm{kWh} / \mathrm{M} * 14\rangle$ と推定している。図 3 に示した月別電気使用量に 月別ガス使用量*15) を電力に変換したものを加算する*16) と、関電 エリア内のオール電化住宅での電力使用量は平均 $778 \mathrm{kWh} / \mathrm{M}$ (年間 $9,335 \mathrm{kWh} / \mathrm{Y})$ 、最大值が1月の $1,024 \mathrm{kWh}$ であり、季節変動とし て $900 \mathrm{kWh}$ を越える月は11〜1月と8〜9月であった（図 4)。 $905 \mathrm{kWh} / \mathrm{M}$ に比べて少ない数値となったのは、算出のための元デー 夕である電気及びガス使用量の実績值には、戸建て住宅だけでは なく、使用量の少ない集合住宅や単独居住者のデータも含まれて いるためであると思われる。関電エリア全域でのオール電化住宅 月平均電力使用量推定值に比べ、京都市内では $777 \mathrm{kWh} / \mathrm{M}$ (9, 320kWh/Y) で、大きな違いは見られないが、1月の最大值が 1, $033 \mathrm{kWh}$ と関電エリア内の平均を上回るのは、冷え込みの厳しい 地域特性のためと思われる。

実験住宅に住む夫婦 2 人の前住宅での生活は、電気・ガス併用 でガス暖房を利用していた。前住宅での住まい方を基に、ガス使 用量を電力に変換し、オール電化の実験住宅での電力使用量を求 めると、 $886 \mathrm{kWh} / \mathrm{M}$ となった。ただし、暖房をガスに頼っていたた

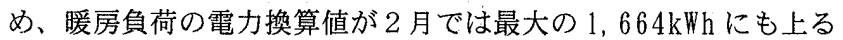
と予測された。

\section{3-4 夏期における電力需要と負荷軽減}

暖房を必要としない期間の $5 \sim 9$ 月を夏期と定め、その間の電 気エネルギーの収支を見ると、実験住宅においては、推定使用電 力量の合計が $3,013 \mathrm{kWh}$ 、推定発電量が $1,234 \mathrm{kWh}$ であり、4 割近 く電力を賄えた（図 5 )。

実際の電力使用量 (計 $2,524 \mathrm{kWh}$ ) と発電量 (計 $1,193 \mathrm{kWh}$ ) を見る と、月平均 $48 \%$ の電力が自宅の太陽光発電で供給できる計算にな り、一ヶ月あたりの月平均買電量は $266 \mathrm{kWh} / \mathrm{M}$ であった。これは、

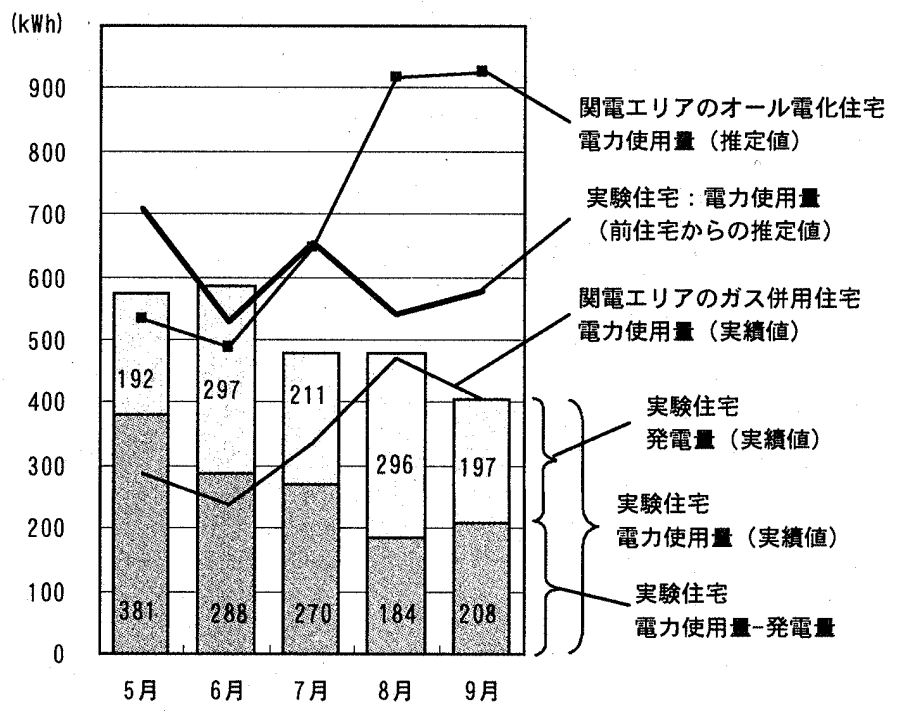

図 5 実験住宅の電力使用量と発電量及び関電エリア内の住宅の電力使用量 
関電エリア内の夏期における一般なガス併用住宅一軒あたりの月 平均電力使用量 ${ }^{* 9}$ (実績値) $346 \mathrm{kWh}$ (5〜9月計 $1,722 \mathrm{kWh)より}$ も下回る。電力会社から供給を受けた一ケ月あたりの電力量を $\mathrm{CO}_{2}$ 排出量に換算すると、実験住宅は $74.5 \mathrm{~kg}-\mathrm{CO}_{2} / \mathrm{kWh}$ 、一般的 なガス併用住宅では $96.9 \mathrm{~kg}-\mathrm{C} 02 / \mathrm{kWh}$ となる。

データを見て分かるように、実験住宅では一般に中間期と言わ れる $5-6$ 月よりも $7-8$ 月の電力使用量が減少していることが 分かる。居住者に、電力使用量が減少した要因として考えられる ことがないか尋ねたところ、(1)実験住宅へ引つ越し後しばらく は、電気器具の使用法に不慣れであり消し忘れなどがあったが、 新しい住宅にも慣れ、待機電力をはじめ各種節電を気にするよう になったこと、(2)例年 7 月の電気代の請求が来てから 8 月にエア コン使用をひかえるようにしていたが、実験住宅では、建具を開 放し天公を開けた状態で扇風機を利用すれば、充分快適であった ため、エアコンを使用する必要を感じず、来客時や帰宅後の数分 部屋を冷やす程度であった、(3)表示パネルで発電量を確認し、発 電量が少ないときは電化製品を使うことを躊躇した、という回答 を得た。居住者の電力使用量に対する興味と、節電への意識の高 まりが、電力使用量を削減する効果を与える要因であることが分 かった。

夏期における電力使用量を最も増加させる冷房負荷について は、実験住宅では目立った増加を来さなかったことが分かった。 建築条件は変わったものの、周辺環境や生活習慣も前家とほぼ変 わりなく、冷房は日中に数時間の使用程度で斉むと予測をしてい

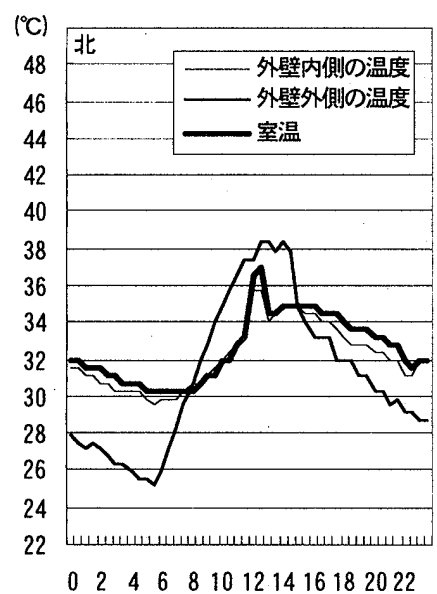

( $\left.{ }^{\circ} \mathrm{C}\right)$

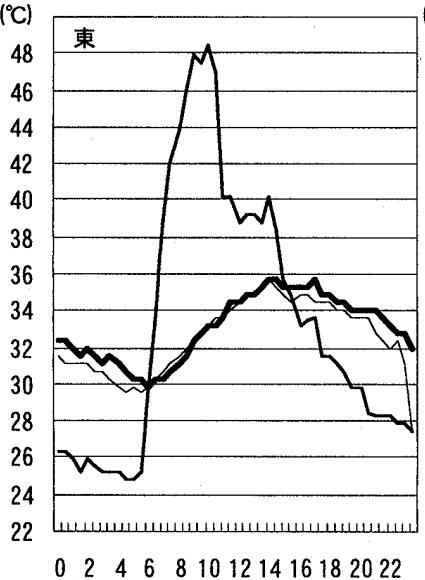

图 6 外気温及び室温の日変化（8月 2 日）

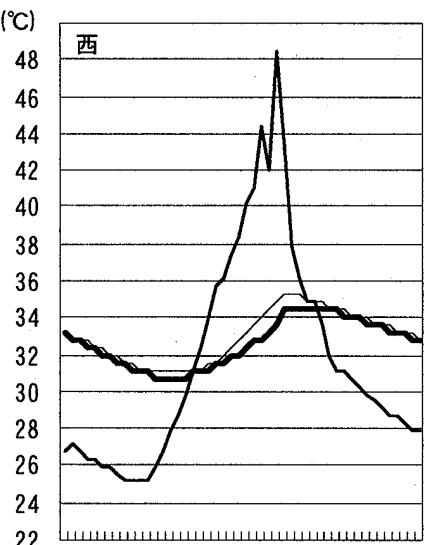

02246810121416182022

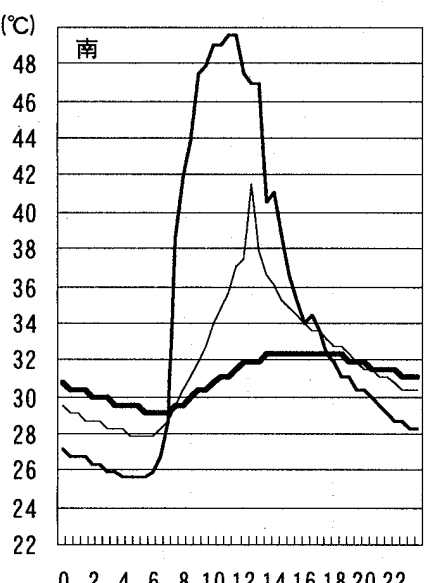

022466810121416182022
たが、実際に、冷房の利用は $7 〜 9$ 月を通じて数時間に満たな かった。冷房利用を抑えられた要因は、まず、壁内に空気層を設 けた効果として、屋内の温度が外気によって影響を受けにくく、 あまり上昇しなかったことにある。

東西南北 4 力所の空周辺にロガーを設置し、外壁外表面近傍 （以下、外壁外側とする）の温度と、外壁内表面近傍（以下、外 壁内側とする）の温度と、室内の温湿度を測定した結果、最高気 温を記録した 8 月 2 日も、エアコンを使用せずに済んだことが分 かった（図 6 )。日変化を見ると、北側の外壁内側の温度と室温 が不自然な上昇を見せるが、これは隣家がエアコンを使用したた め室外機のファンにより、北側の空より外気が流入したからであ る。南側の外壁内側が、正午を中心に高くなっているのは、温度 センサー周辺の壁が、公からの日射の影響を受けたためである。

四方とも室温と外壁内側の温度に対し、外壁外側の温度が日中 は明らかに高く、夜間は低くなっていることから、外壁を二重構 造としたことによる効果であると考える。特に、南側の室温が、 他の 3 方と比べて $2{ }^{\circ} \mathrm{C} ほ と ゙$ 低くなっているのは、庇を深くしたこ と、植え込みがあることも要因と考えられるが、外壁の空気層が 他の三方 $(12 \mathrm{~mm})$ に比べ厚い $(110 \mathrm{~mm})$ ためでもあると考える。

日中に屋内が温室化し、室温が上昇するのではなく、緩やかに 温度変化を見せているのは、1 階から 2 階への小公をはじめとす る、空間を仕切る建具を開放し、室内の熱い空気を天公から排気 した効果もある。真夏の日中時*17)に、天空の直下において階下 からの上昇気流を計測したところ、一時的に $2 \mathrm{~m} / \mathrm{s}$ を記録した。 敷地内の外部で正午の気温が $42^{\circ} \mathrm{C}$ を記録したこの日*18)、屋内の 温度は $36^{\circ} \mathrm{C}$ 以上にはならなかった。建設時の工夫により、室温調 節効果があることが実証された。

\section{3-5 電力供給ピーク時の負荷軽減}

電力需要が最大になるのは、真夏の昼間である。平成 13 年度

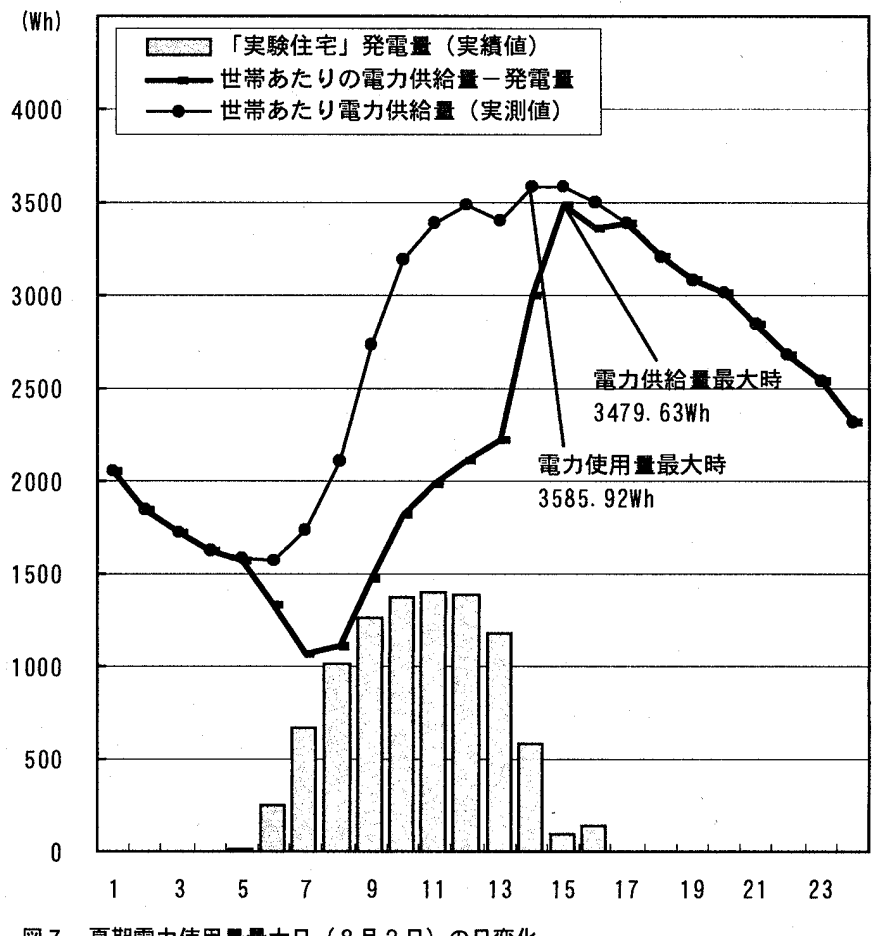

关 7 夏期電力使用量最大日（8月 2 日）の日変化 


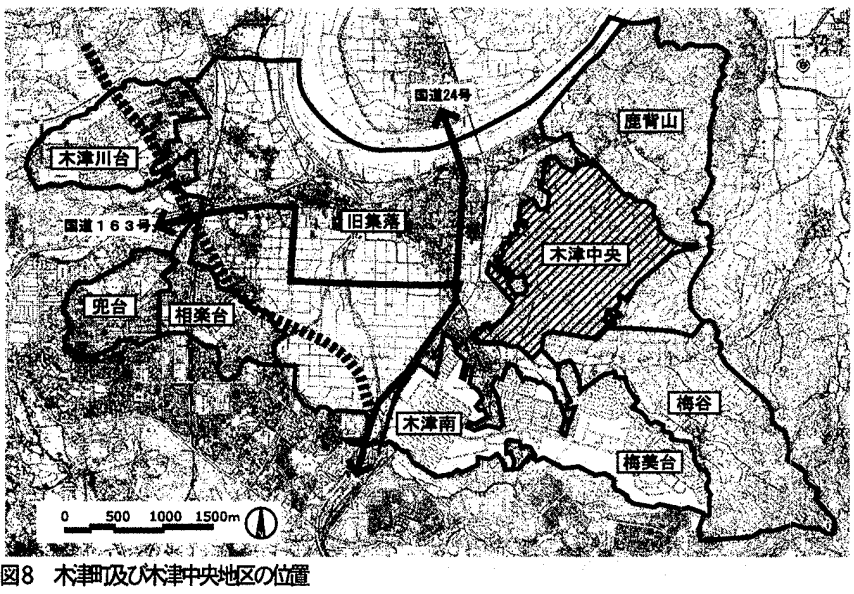

においては 8 月 2 日の 3,306 万 $\mathrm{kW}$ であった。ピーク時の電力需 要による負荷は年々增大している*19)。電力使用量最大日の世帯 あたりの電力供給量と、実験住宅における実際の太陽光発電量 （図 7) を重ねてみると、電力使用量最大時であった 14 時の電力 供給量 3,585.92Wh) の内、発電 $(586.67 \mathrm{Wh}$ ) により $16.4 \%$ 相当の 電力を自給できたことを示す。この日は雲の影響で夕刻より日射 が得られず後の早い時間より発電が終了してしまったが、通常 は 19 時頃まで発電があるため、条件が良ければさらに高い効果 が期待できる。

\section{4 木津中央地区でのエネルギー負荷軽減 \\ 4- 1 木津町木津中央地区}

京都府相楽郡木津町は京都府の南端、奈良市の北に位置する。 京都市と大阪市の双方から $30 \mathrm{~km}$ 圈であり、ベットタウンとして も期待されていた。関西文化学術研究都市建設促進法、関西文化 学術研究都市の建設に関する基本方針及び関西文化学術研究都市 の建設に関する計画に沿って、文化学術研究機能を備えた新市街 地の建設が進められている。現在計画中の地域は 4つあるが、そ

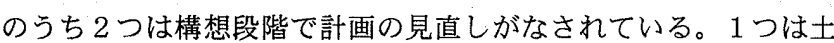
地の整備が既に終了しており、建物の建設が始まりつつある。本 研究でのモデル地区は計画が終了し着手前の「木津中央」地区 （図 8 ）である。この地域において、今後建設する住宅に太陽光

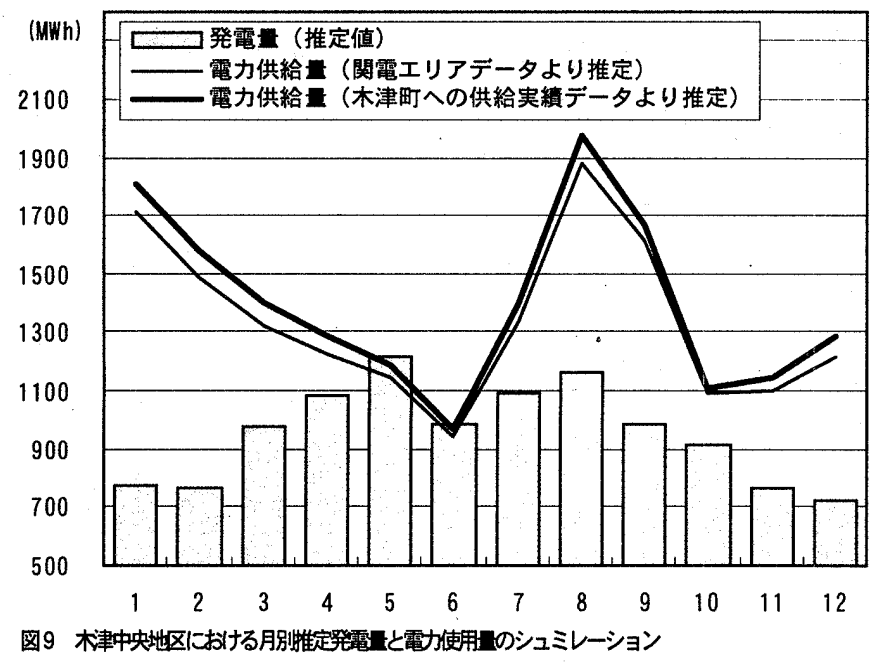

発電システムを導入し、設計施工時に通風・換気などの工夫をす ることによって環境負荷がどのくらい削減されるか、シュミレー ションを行った。

\section{4-2 街区単位での太陽光発電採用による効果}

木津中央地区でシュミレーションを行う場合に加味する要素は (1)日射量などの自然的地域特性、(2) 4000 戸分の住宅用地の分譲 が予定されており、地区内の住宅がすべて新築されること、(3)新 市街地への電力供給量は旧市街地に比べて多い、と言うことであ る。

地域内に建設される住宅すべてに実験住宅と同等の太陽光発電 システムを同じ程度の傾斜角で設置すると仮定し、現行の住宅計 画図より設置方位を検討したところ、約 6 割が真南、あとの 2 割 ずつが南東と南西に向けるものとした。一軒当たりの発電量推定 值は、設置面が真南の場合 $2,904 \mathrm{kWh} / Y$ 、南東が $2,802 \mathrm{kWh} / Y$ 、南 西であると2, $803 \mathrm{kWh} / \mathrm{Y}$ であり、実験住宅の発電量推定値の 2, $530 \mathrm{kWh} / \mathrm{Y}$ （図 3 ）に比べ、高くなっているのは、実験住宅の 建設地である京都市より、木津町の月平均傾斜面日射量が多いこ とに起因する。木津中央地区に建設される全住宅で太陽光発電シ ステムを導入した場合、 $11,453 \mathrm{MWh} / \mathrm{Y} * 20)$ の発電が可能である (図 9)。これは、CO2 削隇に、3, 207t-C の貢献が期待できる。 近畿圏内での住宅新築時における太陽光発電導入率である、 $5.7 \% * 211$ で算出すると、発電量は $653 \mathrm{MkWh} / \mathrm{Y} 、 \mathrm{CO} 2$ 削減量は、 $183 \mathrm{t}$-Cにとどまる。ただし、住宅新築時の導入は年々増加して いる*22)ことからも、今後建設されるこの地域では高い導入率が 期待できる。

現在木津町では町民の半数以上が新市街地に住んでおり、既成 市街地に住む住民に比べ、若い世代が多い。また、住宅が新し く、電化率も高いと考えられる。木津町への電力供給量も関電工 リア全体に比べて高くなっている。同町内に建設される木津中央 地区も、同じような特徴を見せることが考えられるため、地域全 体としての電力使用量は、平均より多い木津町への電力供給量か ら算出した。地域内の対象戸建て住宅群の年間電力使用量は、 $16,818 \mathrm{MWh} / \mathrm{Y}$ となる。地域に建設される住宅全てが太陽光発電シ ステムを導入したとして電力使用量のうち $68 \%$ 、新築時の導入率 を考慮に入れると約 $3.9 \%$ の電力を自家発電で供給できる。

\section{5 結論}

新たな実験住宅の実測值により、興味深いデータが得られた。 発電量 $3 \mathrm{kWh}$ 程度のパネルを設置した場合のエネルギー負荷低減 効果として、(1)ガス併用の一般住宅であれば電力使用量の 7 割程 度を、オール電化であっても自家発電で 4 割近くを賄える、(2)設 置したことによる 2 次的効果として、居住者の省エネルギーに対 する意識の向上が見られ、結果として電力の使用量そのものが削 減できる可能性があるといえる、(3)新築時に導入するのであれ ば、外壁の断熱や屋内外の空気の流れの導線を計画に組み込むな ぞ、自然環境を利用した設計を行うことによって、エネルギー負 荷削減に貢献ができる。また、(4)木津中央地区へのシュミレー ションでは、一定の効果が望め、新築時の導入が大いに期待でき ることを予測した。 
本稿では夏期のエネルギー負荷にを対象に考案したが、次稿で は冬の暖房負荷時での効果を検証する。その際、蓄熱式の床暖房 の効果もあわせて考察を行いたい。

\section{謝辞}

電力供給量 (使用量) に関するデー夕については、関西電力 (株) より提供していただいた。ガスエネルギー使用量に関するデータ は、大阪ガス (株)に、また、発電量シュミレーションについて は、京セラ (株)にご協力いただいた。実験住宅における実測デー 夕を収集するに当っては、応地家の全面的協力を得た。ここに記 して感謝の意を表す。

\section{註}

*1)「環境共生地域の概念探求と計画化 〜京都府木津町を事例として〜」 文部科学省科学研究費補助研究、日本学術振興会特別研究員 今川朱美、 2001 年 4 月〜 2003 年 3 月。

*2) 文献 19] [10] [13]

*3) 文献 [6] [7] [8]

*4) 冬木隆 : 2.3 多結晶シリコン太陽電池の現状と課題, 文献 [1]

*5) 文献 [1] [2] [3] [4] [5] 及び京セラ(株) S E 商品技術部 柿添氏らのヒヤリング による。

*6) 京セラ (株) SE 事業推進部営業企画 増井氏の協力による。

*7) 月平均日積算斜面日射量算出には、「rbモデル（斜面日射量㨁達成分モデル）」 「Hay モデル（斜面日射量天空散乱成分モデル)」「均一反射モデル（斜面日射地 点反射成分モデル)」を用いている。なお、今回の推定值算定のための日射量は、 (財) 日本気象協会 : 太陽光発電システム実用化技術開発「発電舅基礎調査」

S62.3 による、1961 年から 1990 年の 30 年間の平均值を使用している。

*8）損失因子に対し次のような補正係数を与えている。

$\mathrm{K}=\mathrm{Kpt} \cdot \mathrm{Kw} \cdot \mathrm{Ke} \cdot \mathrm{Kc}$

$K p t:$ 太陽電池素地の温度上昇による損失の割合

$(12 \sim 2$ 月 $=0.90)(3 \sim 5 \cdot 9 \sim 11$ 月 $=0.85)(6 \sim 8$ 月 $=0.80)$

KW : 配線、受光面の污れ、逆流防止ダイオードによる損失などの補正値 $=0.92$

Ke : モジュール設置方法による損失の補正値（屋根材型 $=0.98)$

$\mathrm{Kc}$ : 電力変換効率に伴う損失（エコノライン 401 の場合 $=0.945$ ）

文献 [15] [16] を参考に（株）京セラの指導により、温度上昇による損失の割合 を従来のものよりも損失条件を厳しくした。

*9) 関西電力 (株) 滋賀支店お客様室提供による。関西電力の電力供給エリア内の

「一般家庭における月別㮸量暼灯 $\mathrm{A}$ 契約使用電力量 (=従量電灯 $\mathrm{A}$ 契約供給電力

量 $\div$ 従量電灯 $\mathrm{A}$ 契約口数）2000.9-2001.8」従量電灯 A 契約とは、電気ガス併用 一般家庭用の契約である。年々電力使用量は增加しているので、入手可能な最新 データを使用している。

*10) $\mathrm{C} 02$ 排出量原単位 $=0.28 \mathrm{~kg}-\mathrm{CO} 2 / \mathrm{kWh}(2000$ 年度) 関西電力 (株)「地球環境

アクションレポート 20011 。現在は、関西電力が電力業界で最も低い水準である。 本研究の実験住宅及び対象地域である木津中央地区は、関電エリアであるためこ の数値を使用した。電力業界全体では、0.371 kg-C02/kWh:電気事業連合会「電 気事業における環境行動計画 2001」

$0.328 \mathrm{~kg}-\mathrm{CO}_{2} / \mathrm{kWh}$ : 東京電力 (株)「TEPC0 環境行動レポート $2001 」$

$0.425 \mathrm{~kg}-\mathrm{C} 02 / \mathrm{kWh}$ : 東北電力 (株)「地球環境行動レポート 2001

$0.317 \mathrm{~kg}-\mathrm{C} 02 / \mathrm{kWh}:$ 九州電力 (株)「2001 年度境アクションレポート」

*11) 一般の家庭用電気使用量 $=310 \mathrm{kWh}$ : 関西電力（株）電力供給管内 2,000 世帯 を対象にしたサンプリング調查平均值

*12）中間期から紊のガス使用量は最大で $20 \mathrm{~m}^{3}$ (5 月） 8 月は $11 \mathrm{~m}^{3}$ であることか 5、㞓房・給湯ガスの使用量を $20 \mathrm{~m}^{3}$ と仮定する。大阪ガスの調查によると、各 家庭ごとに年間を通じて厨房ガス（単身者を含む平均 $6 \mathrm{~m}^{3}$ ） は注ぼ一定であり、 給湯ガスは冬のピークに向かって直線的に増加することから、菂房・給湯ガスを 1：4 と定めるとその条件を満たす。冬期の $20 \mathrm{~m}^{3}$ を越えた分については、暖房 ガスと考える。

*13) 欴房ガス : ガスコンロ標淮使用量 $\left(9 \mathrm{~m}^{3} \times 40 \%\right)$ を熱量換算し IH 調理器 (熱効 率 78\%) で算出。給湯ガス: $460 \mathrm{~L}$ タイプの電気温水器の標準使用量電気温水器 (減勃率 $90 \%$ ) (社) 日本電機工業会調ベ。ガスファンヒーター (10 畳用)をエアコ ン (10 畳用) で試算。

*14)オール電化住宅一ヶ月あたり電力使用量 $=905 \mathrm{kWh}: 13)+55 \mathrm{kWh}$ (調理機器 電気使用量) $+540 \mathrm{kWh}$ (電気温水器 $460 \mathrm{~L}, 54 \mathrm{~kW}$ )、(社) 日本電機工業会調心゙

*15) 一般家庭ガス使用量 : 大阪ガス (株) 供給管内の全家庭用顧客 545 万件（戸 建住宅 $45 \%$ 、集合住宅 $55 \%$ ）を対象にしたH12 年度の実績による。
*16) 厨房ガス : 年間一律 $=$ 約 $6 \mathrm{~m}^{3} /$ 月 + 給湯ガス : 夏期の最小值 $=$ 約 $12 \mathrm{~m}^{3} /$ 月、 冬期の最大值二約 $40 \mathrm{~m}^{3} /$ 月 + 暖房ガス（大阪ガス調べ）を参考に試算

*17) 2001 年 8 月 3 日、実験住宅に屋内の状態を体感するために滞在した際に測定 を行った。

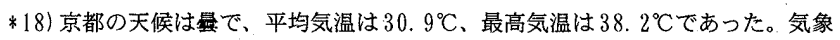
庁月報 2001 年 8 月 (CD-ROM) による。

*19）関西電力（株）平成 13 年度の電力供給管内への電力供給量の実績值による。 *20）発電量の算出は実験住宅と条件を同じにし6) 8)、地域変動のある日射量に ついては7) 木津町から最も近い奈良のデ一タを利用した。住宅により異なる接置 面の方位は現行の分譲計画より 4000 戸のうち 6 割の 2400 戸は南向きに設置し、 それぞれ 2 割の 800 戸が南東と南西向きに設置するものとした。

*21) 導入率：国土省によると平成 12 年度の近畿地域における住宅の新築件数は 58,930 件、関西電力と新規の売電契約締結は 3,395 件。近畿地方における住宅 新筑時の太陽光発電導入は 5.76 パーセントといえる。また、文献 [14]では、 2010 年の日本平均太陽光発電遒入率は 5 パーセントとしている。

*22）新エネルギー財団による。また、関西電力の売電契約締結口数も、97 年 1454 件、98 年 2528 件、99 年 46360 件、2000 年 8031 件、と增加している。

\section{参考文献}

[1]濱川圭弘編著「太陽光発電一最新の技術とシステムー」シーエムシー，2000

[2] 太陽光発電技術研究組合「太陽光発電一その発展と展望一」 朝日新聞社, 1998

[3] 太陽光発電協会 編「太陽光発電システムの設計と施工」 オーム社, 2000

[4] 京セラ(啝ソーラーエネルギー事業部 遍著「太陽エネルギーへの挑戦」精文社 1994

[5] 谷辰夫 : 第 3 章 太陽光発電（清水幸丸編「自然エネルギ一利用学」パワー 社, 1999) pp57-106

[6] 佐々木淑貴，赤林伸一，坂口淳：戸建住宅における電気エネルギー消費に関 する研究一主に東北地方を対象とした太陽光発電の有効性の検討一，日本建築学 会計画系論文集 第 545 号，pp79-86，2001.7

[7] 赤林伸一，坂口淳，田村由香 他：太陽光発電の地球特性に関するシュミ レーションその1 東北地方を対象とした発電と暖房負荷の関係, 日本建築学 会北陸支部（長野）研究報告集，pp 195-198，1997.7

[8] 坂口淳，赤林伸一，山口一：東北 7 県の住宅における電力消費量の実態調査 日本建築学会大会学術講演梗概集 (中国)， D-2，pp151-152，1999.9 [9] 濱田靖弘， 中村真人，落藤澄 他：札幌における家庭用エネルギー消費量と その季時別変動に関する実測と評価、空気調和・衛生工学会論文集 N 0.82 , pp29-37, 2001. 7

[10] 濱田靖弘， 中村真人 他 : 自然エネルギーをハイブリッドに活用したエネル ギ一自立型住宅に関する研究，空気調和・衛生工学会論文集 No. 73，pp105-

$115, \quad 1999.4$

[11]繪内正遺，福島 明，羽山広文：地球環境時代におけるパッシブ省エネル ギー手法の意義とその展開（特集・北海道にみる建築設備と環境技術の変遷之動 向） 空気調和・衛生工学 74-9, pp763-767，2000.9

[12] 長野克則 : 北海道におけるアクティブ省エネルギ一手法の現状と将来展望， （特集・北海道にみる建築設備と環境技術の变遷と動向）空気調和・衛生工学 $74-9, \quad$ pp769-773, 2000.9

[13] 落藤 澄・濱田舷弘 他 : ローエネルギ一ハウスの建設の意義とその可能性 （特集・北海道にみる建築設備之環境技術の変遷之動向）空気調和・衛生工学 $74-9, \quad$ pp781-784, 2000.9

[14]京都市環境局「京都市地域新エネルギービジョン策定調查報告書」H 12.3 [15] 大谷謙 : 2000 年太陽光発電システムの通信簿, （総説「太陽光発電」）日本 エネルギー学会誌 $80-3,2001.3$

[16] 大谷謙仁 他：住宅用太陽光発電システムの運転特性評価, 電気学会新エネ ルギー・環境研究会 No. FTE-00-5，2000.3

[17] H.Scheer, Solare Wertschaft, VAKG, Munchen, 1999 (Japanese edition, 2001) [18] J.Schaeffer \& The Real Goods Staff, Solar Living Source Book, CGPC, USA, 1996

（2002年 2 月 10 日原稿受理， 2002 年 5 月 20 日採用決定） 